\title{
A Nuclear-Polyhedrosis Virus of Spodoptera frugiperda Isolated in Puerto Rico ${ }^{1,2}$
}

\author{
Goro Kuno ${ }^{3}$
}

\begin{abstract}
A nuclear-polyhedrosis virus was isolated from a larva of Spodoptera frugiperda collected in Puerto Rico. The virus was found to be pathogenic to the larvae of Heliothis zea and of S. frugiperda but nonpathogenic to those of Diatraea saccharalis and of Galleria mellonella. LD 50 for the fourth instar larvae of H. zea and S. frugiperda inoculated per os were $1.25 \times 10^{3}$ and $2.7 \times 10^{3}$ polyhedral inclusion bodies, respectively. The tissues infected included hemocytes, fat body, muscle, and epidermis. Furthermore, transovarian transmission of the virus was found in the inoculated individuals of S. frugiperda.
\end{abstract}

\section{INTRODUCTION}

Nuclear-polyhedroses, viral diseases caused by members of baculoviruses, have been recognized in a Lepidopterous insect pest, Spodoptera frugiperda $(1,4)$. Because of their usefulness in controlling insect pests, some of those viruses have been considered as potential viral insecticides $(7,9)$.

During a survey of microorganisms associated with the insects of Puerto Rico, a nuclear-polyhedrosis virus was isolated from a dead $S$. frugiperda larva in Isabela. Because of its potentiality as a microbial pest control agent, the author conducted a series of experiments to elucidate the nature of the virus and of its infection. This article describes morphological characters, virulence, host range, and transovarian transmission of the virus, and histopathology of the viral infection.

\section{MATERIALS AND METHODS}

\section{REARING OF INSECTS AND PROPAGATION OF THE VIRUS}

Heliothis zea, Spodoptera frugiperda, and Diatraea saccharalis used in the experiments were individually reared in plastic cups containing an artificial diet developed previously (10). Galleria mellonella were reared in large bottles with a diet consisting of a "Mixed" cereal powder (Gerber Products Co., Fremont, Michigan) ${ }^{4}$ (208 g), glycerol (66 ml), and pure

\footnotetext{
' Manuscript submitted to Editorial Board May 4, 1978.

${ }^{2}$ The work was done when the author was at the University of Puerto Rico at Mayagüez.

"Present address: Center for Disease Control, San Juan Labs., G.P.O. Box 4532, San Juan, Puerto Rico 00936. Acknowledgment is due to Dr. Jean R. Adams, USDA, Beltsville, Maryland, for her technical assistance in producing electron-micrographs of the virus.

${ }^{4}$ Trade names are used in this publication solely for the purpose of providing specific information. Mention of a trade name does not constitute a guarantee or warranty of equipment or materials by the Agricultural Experiment Station of the University of Puerto Rico or an endorsement over other equipment or materials not mentioned.
} 
honey $(134 \mathrm{ml})$ per $200 \mathrm{ml}$ medium. Laboratory colonies of the insects, as well as virus-treated larvae, were reared in two separate incubators at $28^{\circ} \mathrm{C}$ without light.

For the virus propagation, the original virus-infected larva was homogenized and the homogenate filtered through double layers of cheesecloth. The filtrate thus obtained (crude polyhedra suspension) served as a source of primary inocula for further propagation. Larvae of S. frugiperda (third through fifth instar) were starved for half a day and fed small amounts of the artificial diet contaminated with the crude polyhedra suspension. Those killed by the virosis were collected, homogenized, and the homogenate-was filtered as above. The polyhedra fraction served as a source of the experimental inocula.

\section{MORPHOLOGICAL CHARACTERS OF THE VIRUS}

Size and shape of the viral polyhedral inclusion bodies (PIBs) were studied in wet mounts with a phase-contrast microscope as well as with

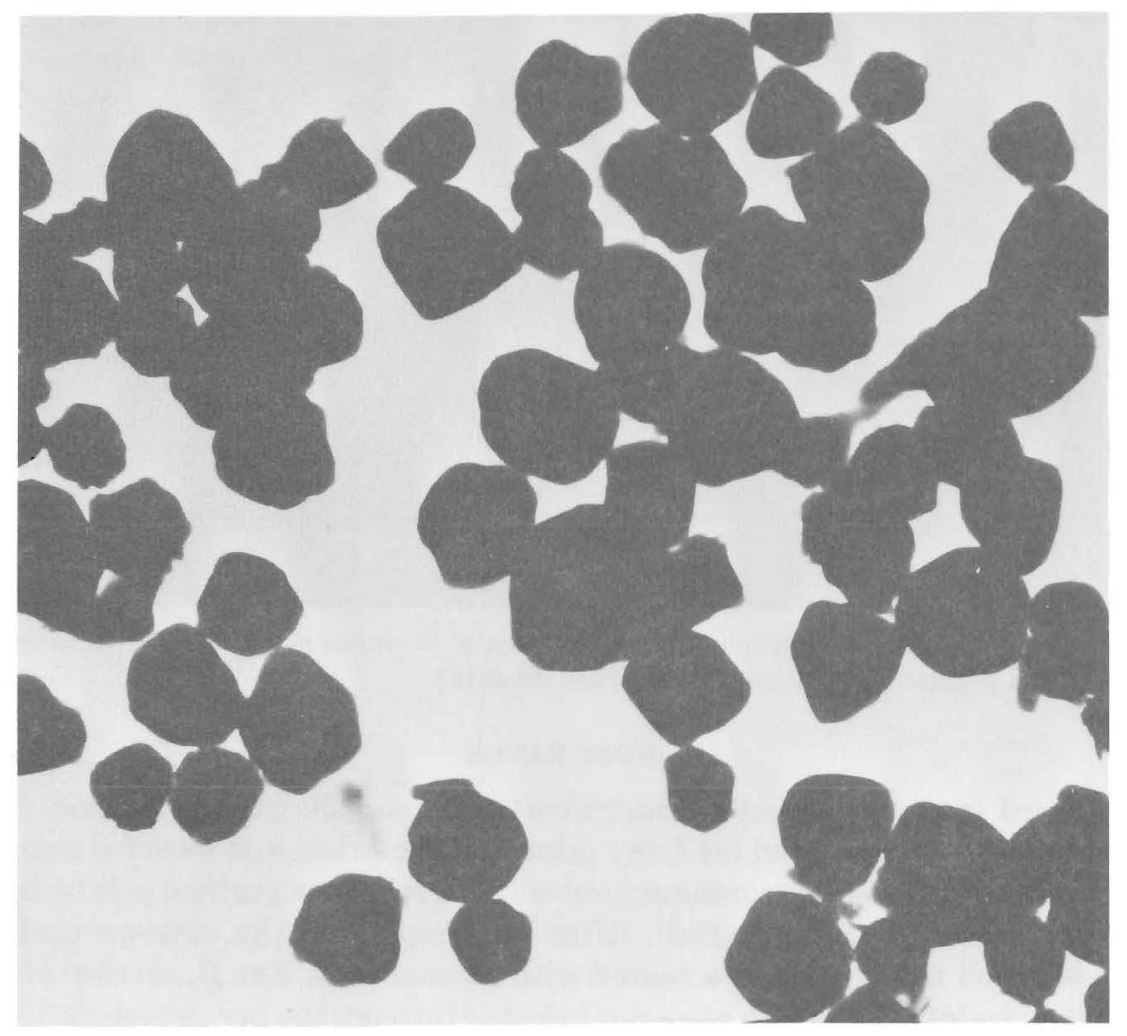

FIG. 1.-Electron micrograph of the polyhedral inclusion bodies of $S$. frugiperda NPV isolated in Puerto Rico $(8,500 \times)$ 
an electron microscope. For electron microscope observation the PIBs were fixed by Dr. Jean R. Adams of Beltsville, Maryland, first with 2.5\% glutaraldehyde and then with $1 \%$ osmium tetroxide, embedded in Dow epoxy resin (No. 334), ${ }^{4}$ and the plastics sectioned with an ultramicrotome. The thin sections of the plastics were examined with an electron microscope (Phillips, Model 301). ${ }^{4}$

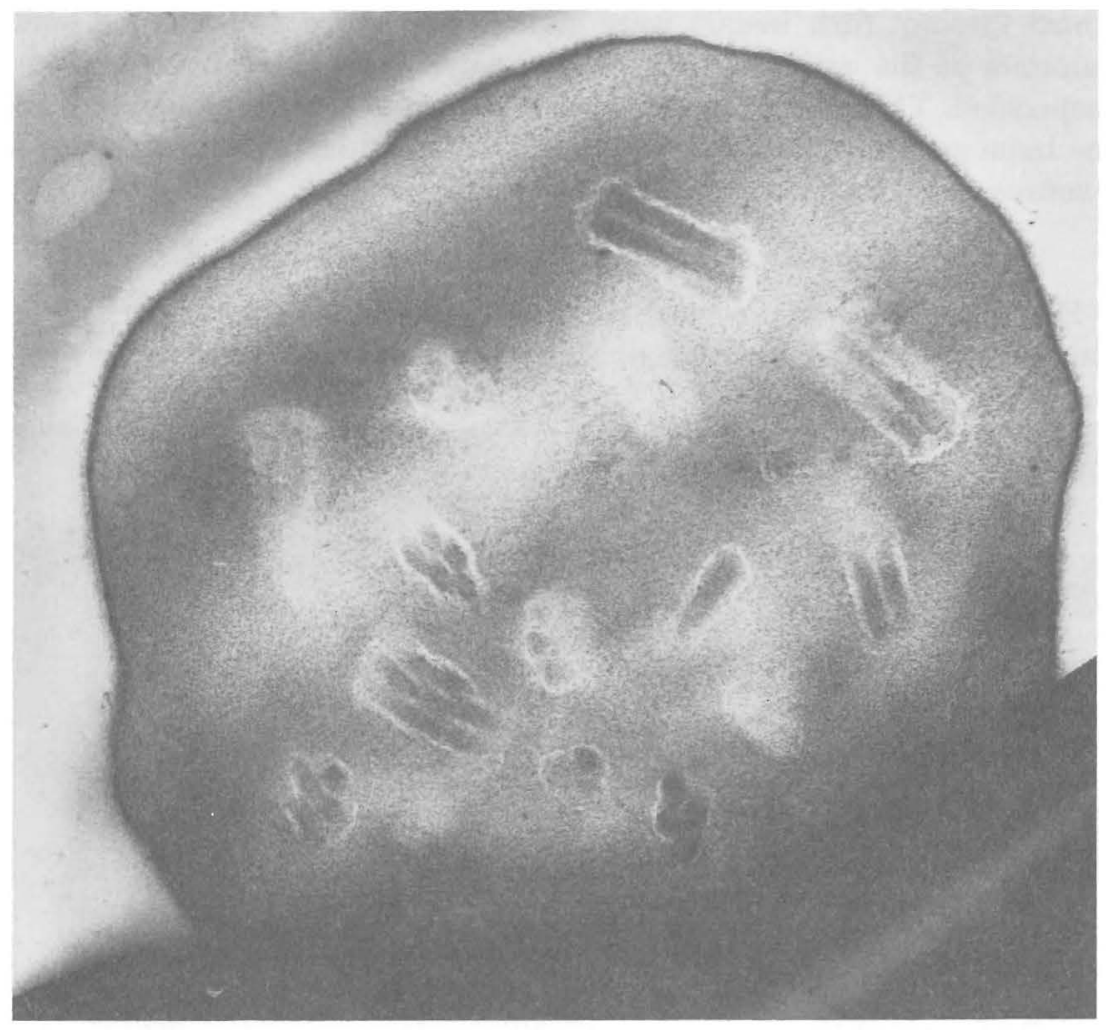

FIG. 2.-Electron micrograph of the ultrastructure of virions in a polyhedral inclusion body of S. frugiperda NPV from Puerto Rico $(58,438 \times)$

\section{HOST RANGE}

Third instar larvae of $D$. saccharalis, H. zea, S. frugiperda and $G$. mellonella were starved for 1 day prior to inoculation, and were fed small pieces of artificial diet contaminated with $0.2 \mathrm{ml}$ of the purified polyhedra suspension $\left(4.7 \times 10^{8} \mathrm{PIBs} / \mathrm{ml}\right)$. After consumption of the virus-contaminated food the larvae were reared with normal food. For $D$. saccharalis and $G$. mellonella, which were not infected through the per os inoculation mentioned above, the author attempted intrahemocoelic injection of 
alkali-liberated virions. The PIBs were dissolved in $0.03 \mathrm{M} \mathrm{Na}_{2} \mathrm{CO}_{3}$ and $0.05 \mathrm{M} \mathrm{NaCl}$ for $2.5 \mathrm{~h}$ and centrifuged, according to the method of Bergold (2). The pellet of liberated virions was dissolved in $1.0 \mathrm{ml}$ of sterile distilled water, and aliquots of 2.4 microliter were injected intrahemocoelically into fourth instar larvae.

\section{VIRULENCE}

Larvae were anesthetized in carbon dioxide gas. Virulence was studied with per os inoculation of 100 anesthetized fourth instar larvae of $S$. frugiperda and $H$. zea with doses of $10^{2}, 10^{3}, 10^{4}$, and $10^{5} \mathrm{PIBs} ;{ }^{5}$ a syringe was attached to a microapplicator. The inoculated larvae were fed the artificial diet, and the mortality by the virosis was recorded.

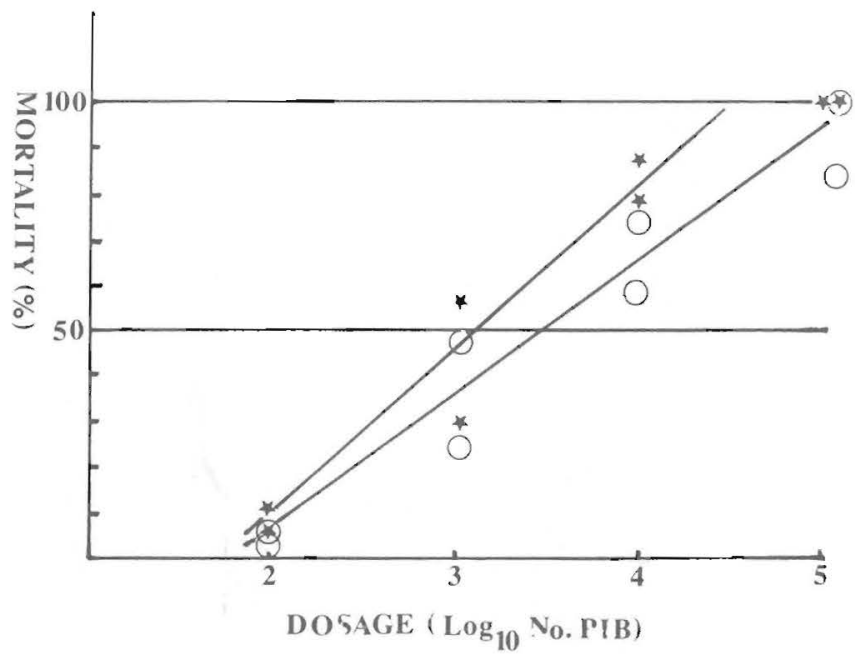

FIG. 3.-Dosage-mortality relationship of S. frugiperda NPV (Puerto Rico isolate) with the larvae of $H$. zea and of S. frugiperda. $\star$ Heliothis; $\bigcirc$ Spodoptera

\section{HISTOPATHOLOGY OF VIRAL INFECTION}

Third instar larvae of $S$. frugiperda were fed virus-contaminated artificial diet. Portions of the treated insects were collected at 6 -h intervals and fixed in hot alcoholic Bouin solution. The tissues were dehydrated in a series of ethanol (50-100\%), cleared in methanol, methylbenzoate, and benzene, and finally embedded in paraffin. The paraffin-embedded tissues were sectioned in thicknesses of 8 microns and stained with an azan stain according to Hamm (6).

${ }^{5}$ After the study was concluded, it was found that a small portion of the PIBs was singleembedded, while the majority was multiply-embedded. Therefore, the inoculum was heterogeneous in composition. 


\section{TRANSOVARIAN TRANSMISSION}

Fifth instar larvae of S. frugiperda were fed food contaminated with $0.5 \mathrm{ml}$ each of purified polyhedra suspension $\left(4.7 \times 10^{8} \mathrm{PIBs} / \mathrm{ml}\right)$. Adults that emerged from those larvae were allowed to mate. The egg masses obtained from 10 different females were surface-sterilized with $0.5 \%$ sodium hypochlorite solution for $20 \mathrm{~min}$, rinsed in sterile water and incubated at $28{ }^{\circ} \mathrm{C}$. The hatched larvae were reared with regular diet. Portions of the eggs, as well as all diseased larvae, were examined microscopically for the detection of PIBs. The sterilized water used for rinsing the eggs, previously treated with sodium hypochlorite solution, was smeared on top of the artificial diet, and healthy larvae (second and third instars) were fed the treated diet. That the larvae developed no virosis confirmed the efficacy of the surface sterilization.

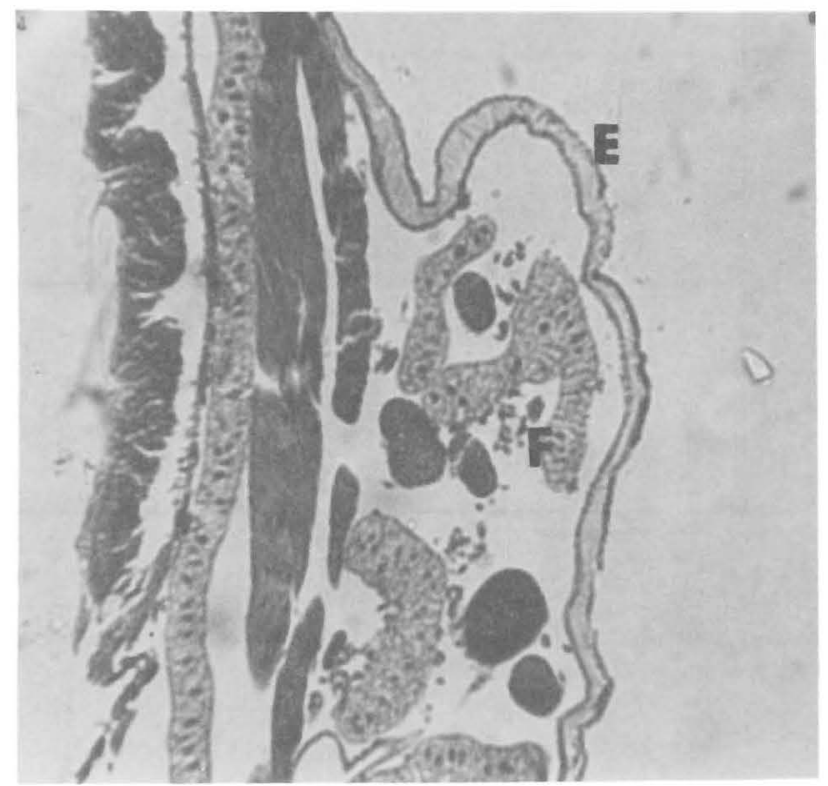

Fig. 4,-Section of a normal S. frugiperda larva. E: epidermis; F: fat body (400X)

\section{RESULTS AND DISCUSSION}

The results obtained in the present studies revealed irregular shape and size of PIBs in the Puerto Rico isolate of S. frugiperda NPV, as is evident in figure 1. The diameter of the longest axis of the PIBs ranged from 0.59 to 2.23 microns in wet mount. Thin sections of the PIBs demonstrated rod-shaped virions multiply-embedded and surrounded with at least two membranes (fig. 2), which resembled the NPV of $S$. 
frugiperda studied by Bergold (3). In addition, a small fraction of the PIBs in the Puerto Rico isolate was found to be singly-embedded (or SEV). Since SEV was also previously reported from NPVs of H. zea, S. frugiperda, and Trichoplusia ni (5), heterologous composition of PIBs, in terms of the mode of occlusion of virions in viral polyhedra, appears to be common in the natural populations of NPVs affecting various species of Noctuidae.

The virus infected $H$. zea and $S$. frugiperda, both of which are Noctuidae. However, neither per os nor intrahemocoelic inoculation induced the virosis in D. saccharalis or in G. mellonella; this fact indicates a strong host specificity at the family level. Although host specificity is often used as one of the important criteria for the classification of baculoviruses, similarities in morphological characters and host

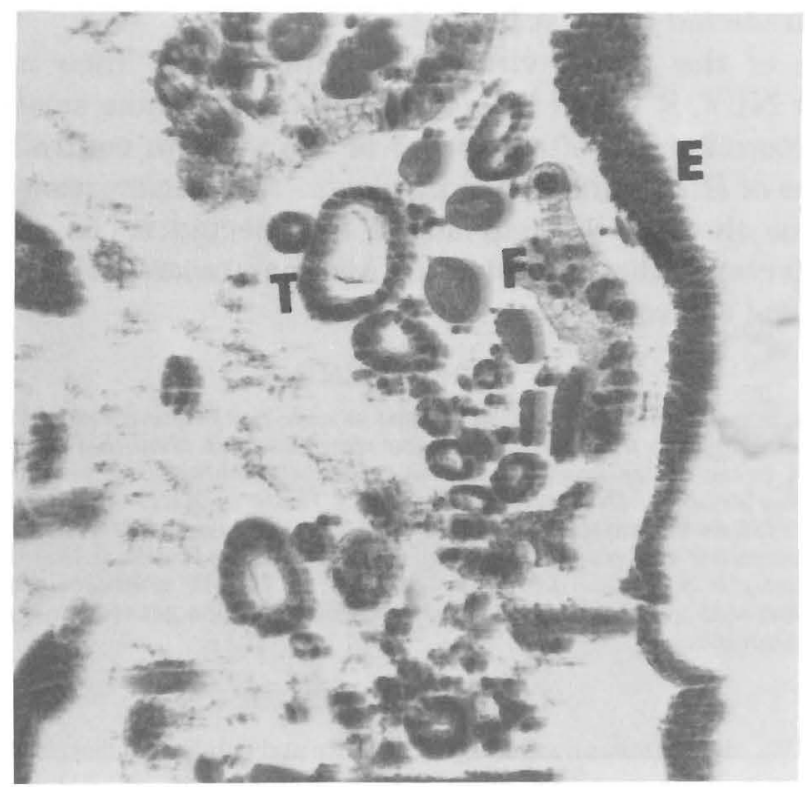

FIG. 5.-Section of an infected S. frugiperda larva. E: epidermis; F: fat body; T: trachea $(400 \times)$

range alone do not necessarily prove that the Puerto Rico isolate is identical to the NPV of S. frugiperda discovered elsewhere, because of a criticism on the conventional classification of baculoviruses (9). Furthermore, a recent DNA homology study of 4 NPVs isolated from 4 closelyrelated species of Spodoptera revealed a wide range of difference (8).

Figure 3 shows a dosage-mortality relationship of the viral infection in S. frugiperda inoculated per os. From the results obtained, $\mathrm{LD}_{50}$ for the 
fourth instar larvae of $H$. zea and S. frugiperda were calculated as $1.25 \times 10^{3}$ and $2.70 \times 10^{3} \mathrm{PIBs}$, respectively. It is evident that $H$. zea is more susceptible to the virus than $S$. frugiperda.

In contrast to normal tissues (fig. 4), histological examination of the infected insects revealed that hemocytes, fat bodies, muscles, and epidermis were heavily infected with the virus, showing densely stained aggregates of PIBs in nuclei (fig. 5). Extensive destruction of fat bodies and epidermis was often detected within 2 days after inoculation. Hypertrophy of the infected nuclei, which is common in the infection by other NPVs, was also observed (fig. 5).

Although the examinations of the eggs laid by virus-inoculated females did not reveal any PIBs, $1.6 \%$ of the hatched larvae died of the nuclear polyhedrosis. Since it was reported that the transovarian transmission of polyhedrosis viruses was actually trans-ovum transmission, the present result contradicted the past finding.

Because of the strong virulence of the Puerto Rico isolate of $S$. frugiperda NPV, it would be worthwhile to undertake small scale field tests to determine the effectiveness of the virus in controlling natural populations of $H$. zea and of $S$. frugiperda. The transmission mechanism of the virus through infected adults is expected to be an additional favorable factor in the dissemination and maintenance of the viral agent in the natural environment.

\section{RESUMEN}

Un baculovirus (virus de núcleo-poliedrosis) se aisló por primera vez en Puerto Rico, de una larva de Spodoptera frugiperda. Se infectaron larvas de Heliothis zea asi como de S. frugiperda. A pesar de las inoculaciones intrahemocilial y oral, no se encontró ninguna infección en las larvas de Diatraea saccharalis y Galleria mellonella, lo que indica una gran especificidad de los huéspedes. Varios tejidos se afectaron, entre ellos cuerpos grasos, hemocitos, músculo y epidermis. Se determinó que las dosis letales ( $\mathrm{LD}_{50}$ ) del virus en las larvas de $H$. zea y le $S$. frugiperda fueron $1.25 \times 10^{3}$ y $2.70 \times 10^{3}$ poliedros, respectivamente. También se encontró que el virus puede ser transmitido de una generación a otra por medio de huevos contaminados.

\section{LITERATURE CITED}

1. Allen, H. W., 1921. Notes on a Bombylid parasite and polyhedral disease of the southern grass worm, Laphygma frugiperda. J. Econ. Entomol., 14, 510-511.

2. Bergold, G. H., 1963. The nature of nuclear-polyhedrosis viruses, In: "Advanced Treatise in Insect Pathology," E. A. Steinhaus, Ed, Academic Press, New York, N.Y., vol. 1, pp. 413-456.

3. Bergold, G. H., 1963. Fine structure of some insect viruses, J. Insect Pathol., vol. 5, 111128.

4. Chapman, J. W. and R. W. Glaser, 1915. A preliminary list of insects which have wilt, with a comparative study of their polyhedra. J. Econ. Entomol., vol. 8, 140-149.

5. Goodwin, R. H. et al., 1973. The influence of insect cell lines and tissue-culture media on baculovirus polyhedra production. Misc. Publ. Entomol. Soc. Am., vol. 9(2): 6672.

6. Hamm, J. J., 1966. A modified azan staining technique for inclusion body viruses, J. Invertebr. Pathol., vol. 8, 125. 
7. Ignoffo, C. M., 1968. Viruses-living insecticides, Curr. Top. Microbiol. Immunol., vol. 42, 129-67.

8. Kelly, D. C., 1977. The DNA contained by nuclear polyhedrosis viruses isolated from four Spodoptera sp. (Lepidoptera, Noctuidae): genome size and homology assessed by DNA reassociation kinetics, Virol., vol. 76, 468-71.

9. Summers, M. et al., 1975. "Baculoviruses for Insect Pest Control: Safety Considerations." Am. Soc. Microbiol. Wash. D.C.

10. Walker, D. W. et al., 1966. Improved xenic diets for rearing the sugarcane borer in Puerto Rico, J. Econ. Entomol., vol. 59(1): 1-4. 